Al-Manhaj: Journal of Indonesian Islamic Family Law, 2 (1), 2020: $31-46$

ISSN: 2715-003; E-ISSN 2714-5514

DOI: http://dx.doi.org/10.19105/al-manhaj.v2i1.3076

\title{
WARIS BEDA AGAMA \\ (Analisis Putusan Perkara Kewarisan Beda Agama Dalam Putusan MA 16/Kag/2018)
}

\author{
Imamatus Shalehah \\ (Institut Agama Islam Negeri Madura, imamahshalehah@gmail.com)
}

\begin{abstract}
Abstrak:
Salah satu penghalang ahli waris untuk mendapatkan haknya adalah karena faktor berbeda agama. Namun demikian, Islam masih mempunya alternatif hukum agar ia bisa mendapatkan bagian harta peninggalan pewaris. Metode wasiat wajibah merupakan penalaran yang pas untuk menyelesaikan konflik ahli waris non-Muslim. Hal ini rupanya tidak senada dengan Putusan MA 16/Kag/2018 dalam mengadili perkara kasasi mengenai pembagian harta warisan kepada ahi waris nonmuslim. Di mana dengan surat keputusan itu MA telah membatalkan putusan pengadilan Agama Tinggi Makassar Nomor: 59/pdt.G/ 2009/PTA yang sebelumnya telah membagi harta peninggalan tersebut dengan sistem wasiat wajibah. (One obstacle to the heirs to get their rights is due to different religious factors. However, Islam still has alternative laws so that it can get a share of the inheritance inheritance. The obligatory will method is the right reasoning to resolve the conflicts of non-Muslim heirs. This apparently was not in line with the Decision MA 16 / Kag / 2018 in adjudicating a cassation case regarding the distribution of inheritance to nonMuslim heirs. Where with the decree, the Supreme Court has canceled the decision of the Makassar High Religion court Number: 59 / pdt.G / 2009 / PTA which had previously distributed the inheritance property with the mandatory will system.)
\end{abstract}

\section{Kata Kunci:}

Waris, Wasiat Wajibah, Non-Muslim, Putusan MA 16/Kag/2018

\section{Pendahuluan}


Setiap Manusia memiliki metamorfosa kehidupan mulai dari proses kelahiran, proses perjalanan hidup dan peristiwa kematian. Hal ini tentu akan memberikan akibat hukum pada lingkungan hidup manusia, terutama pada orang-orang terdekat baik dekat dalam artian nasab maupun sebab. Kelahiran membawa akibat timbulnya hak dan kewajiban bagi setiap manusia serta timbulnya hubungan hukum antar mereka (anak, orang tua,kerabat dan masyarakat) di lingkungannya. Begitu pula dengan peristiwa kematian yang juga akan membawa akibat hukum yaitu tentang tatacara kelanjutan pengurusan hak dan kewajiban seseorang yang telah meninggal terhadap ahli warisnya.

Dalam suatu kehidupan yang saat ini telah berkembang menjadi sedemikian kompleks, tak dapat dipungkiri akan timbulnya berbagai persoalan tentang banyak hal diantaranya persoalan kewarisan, yang dalam hal ini berkaitan dengan keadilan, persamaan hak dimata hukum juga harta yang sering kali menimbulkan akibatakibat yang tidak menguntungkan bagi salah satu ahli warisnya. Maka dari itu,ilmu kewarisan memiliki peranan yang sangat penting untuk dipelajari dan diamalkan, karena hal ini sangat erat kaitannya dengan lingkup kehidupan manusia khususnya dalam aspek kekeluargaan.

Salah satu pembahasa yang terdapat dalam Kewarisan adalah mengenai tentang sesuatu yang menjadi penghalang kewarisan yang diantaranya adalah perbedaan agama antara pewaris dan ahli watis, tentunya hal ini perlu kita bahas secara mendalam agar ditemukan problem solving sehingga dapat memberikan rasa keadilan bagi keduanya. Oleh karena itu pemakalah akan membahas tentang kewarisan beda agam beserta analisis Putusan MA 16/Kag/2018

\section{Konsep Waris Beda Agama}

Dalam ketentuan hukum Islam beda agama merupakan salah satu penyebab gugurnya hak seseorang untuk menerima warisan hal ini sesuai dengan hadis Nabi yaitu:

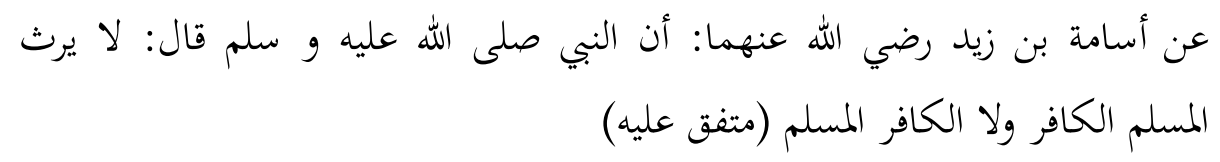


Waris Beda Agama (Analisis Putusan Perkara

Kewarisan Beda Agama Dalam Putusan Ma 16/Kag/2018)

Artinya: Dari Usamah bin Zaid, sesungguhnya Nabi saw. Bersabda: Orang muslim tidak mewarisi orang kafir, dan orang kafir tidak mewarisi orang muslim. (Muttafaq 'alaih)."1

Hadis diatas menjelaskan tentang permasalahan beda agama yang menjadi penghalang mewarisi, yaitu apabila seoarng ahli waris menganut agama yang berbeda dengan pewaris seperti halnya pewaris menganut agama islam sedangkan si ahli waris non muslim. Yang artinya orang muslim tidak akan mewarisi orang non muslim begitupun orang non muslim tidak boleh mewarisi orang muslim.

Nabi SAW sendiri mempraktikkan pembagian warisan beda agama tersebut. Ketika paman beliau, Abu Thalib orang yang cukup berjasa dalam perjuangan Nabi SAW. meninggal sebelum masuk Islam, oleh beliau harta peninggalannya dibagikan kepada anakanaknya yang masih kafir, yaitu 'Uqail dan Thalib. Sementara anakanaknya yang telah masuk Islam, yaitu 'Ali dan Ja'far, oleh beliau tidak diberi bagian. ${ }^{2}$

Perlu kita ketahui bahwa yang menjadi pertimbangan apakah antara ahli waris dan muwarris berbeda agama atau tidak, adalah pada saat muwarris meninggal. Karena pada saat itulah hak warisan itu mulai berlaku. Jadi, misalnya ada seorang Muslim meninggal dunia, terdapat ahli waris anak laki-laki yang belum masuk Islam (non Muslim), kemudian seminggu setelah itu masuk Islam, meski harta warisan belum dibagi, anak tersebut tidak berhak mewarisi harta warisan tersebut. karena yang dijadikan pedoman pada saat pewaris meninggal, bukan pada saat pembagian warisan. ${ }^{3}$

Imam Ahmad ibn Hanbal dalam salah satu pendapatnya mengatakan bahwa apabila seorang ahli waris masuk Islam sebelum pembagian warisan dilakukan, maka ia tidak terhalang untuk mewarisi. Alasannya, karena status berlainan agama sudah hilang sebelum harta warisan dibagi.

1 Al-Imam Abu Abdillah Muhammad Ibn Ismail Ibn Al-Mugirah Ibn Bardizbah Al-Bukhari, Sahih Al-Bukhari, Juz 4, Beirut Libanon: Dar Al-Fikr, 1410 H/1990 M, Hlm. 194

2 Ahmad Rafiq, Fiqih Mawaris, (Jakarta: PT Raja Grafindo Persada, 1993), Hlm. 29

3 Maimun, Pembagian Hak Waris Terhadap Ahli Waris Beda Agama Melalui Wasiat Wajibah Dalam Perspektif Hukum Kewarisan Islam, Jurnal Asas, Vol. IX, No. 1, (Januari 2017), Hlm. 6. 
Sedangkan menurut Yusuf al-Qaraḍawi menjelaskan dalam bukunya yang berjudul Hadyu al-Islam Fatawi Mu'a'sirah bahwa orang Islam dapat mewarisi dari orang non-Islam sedangkan orang nonIslam itu sendiri tidak boleh mewarisi dari orang Islam. Menurutnya Islam tidak menghalangi dan tidak menolak jalan kebaikan yang bermanfaat bagi kepentingan umatnya. Terlebih lagi dengan harta peninggalan atau warisan yang dapat membantu untuk mentauhidkan Allah, taat kepada-Nya dan menolong menegakkan agama-Nya. Bahkan sebenarnya harta ditujukan sebagai sarana untuk taat kepada-Nya, bukan untuk bermaksiat kepada-Nya. ${ }^{4}$

Serta Menurutnya, illat dari masalah waris adalah semangat tolong-menolong, bukan perbedaan agama. Menurut al-AlQaradhawi, illat dalam masalah warisan adalah pemberian pertolongan. Sedangkan adanya perbedaan agama tidak memungkinkan untuk menjadi „illat dalam masalah ini. Ajaran Islam dan umat Islam menolong ahlu dzimmah, maka umat Islam menerima warisan dari mereka, sedangkan ahlu dzimmah -dengan kekafirannya itu- tidak menolong umat Islam, maka mereka tidak menerima warisan dari umat Islam. ${ }^{5}$

Ibnu Taimiyah menyatakan bahwa diantara hal yang menguatkan pendapat orang Islam mewarisi ahli dzimmi dan tidak sebaliknya, adalah bahwa yang dipertimbangkan dalam warisan itu adalah berdasarkan pertolongan, sedangkan penghalangnya adalah permusuhan, oleh karena itu sebagian besar Fuqaha mengatakan bahwa seorang kafir dzimmi tidak mewarisi kafir harbi. Artinya, orang Islam boleh mewarisi orang kafir dzimmi dan tidak untuk orang kafir harbi karena berdasarkan tolong menolong. ${ }^{6}$

Pendapat fuqaha Imamiyah dari pendapat $\mathrm{Mu}^{\prime} \mathrm{adz}$ bin Jabal, Mua'wiyah, Muhammad Ibn al-Hanafiyah, Ali Ibn al-Husein dan Said Ibn alMusayyab mengatakan bahwa larangan mempusakai karena beda agama itu tidak mencakup larangan bagi orang Islam

4 Al-Qaraḍawi, Fatwa-Fatwa Kontemporer, Terjemah Hadyu Al-Islam Fatawi Mu'asirah, Jilid Ke-3 (Jakarta: Gema Insani Press, 2002), Hlm. 850.

${ }^{5}$ Chamim Tohari, Rekonstruksi Hukum Kewarisan Beda Agama, Mazahib Jurnal Pemikiran Hukum Islam, Vol. XVI, No. 1 (Juni 2017), Hlm 7

6 Maimun, Pembagian Hak Waris Terhadap Ahli Waris Beda Agama Melalui Wasiat Wajibah Dalam Perspektif Hukum Kewarisan Islam, Hlm. 185 
Waris Beda Agama (Analisis Putusan Perkara Kewarisan Beda Agama Dalam Putusan Ma 16/Kag/2018)

mewarisi kerabatnya non-Muslim. Oleh karena itu, misalnya bila seorang istri kafir kitabiyyah wafat, suaminya yang beragama Islam dapat mewarisi harta peninggalannya. Agama Islam itu tinggi, ketinggian agama Islam membawa juga ketinggian martabat umat Islam, sehingga mereka dibenarkan mewarisi keluarganya yang tidak beragama Islam, tetapi tidak sebaliknya orang-orang yang tidak beragama Islam dapat mewarisi keluarganya yang beragama Islam. Disamping itu, mereka menyamakan hal itu dengan wanita-wanita orang kafir yang boleh dikawini. Mereka berkata, "Kami boleh mengawini wanita mereka, tetapi kami tidak diperbolehkan mengawinkan mereka dengan wanita kami, makabegitu halnya dengan hal warisan". ${ }^{7}$

Adapun mengenai orang murtad, ulama memandang mereka mempunyai kedudukan hukum tersendiri. Hal ini karena orang murtad dipandang telah memutuskan tali syari'ah dan melakukan kejahatan agama. Karena itu, meskipun dalam isyarat al-Qur'an bahwa mereka dikatagorikan sebagai orang kafir, ulama menyatakan bahwa harta warisan orang murtad tidak diwarisi oleh siapapun, termasuk ahli warisnya yang sama-sama murtad. Harta peninggalannya dimasukkan ke baitul mall sebagai harta fai' atau rampasan, dan digunakan untuk kepentingan umum. ${ }^{8}$

Imam Hanafi dikutip dari jurnal Ilyas memberi ketentuan, apabila orang yang murtad memiliki harta yang diperoleh ketika dia masih memeluk Islam, dapat diwarisi oleh ahli warisnya yang Muslim. Selebihnya, dimasukkan ke baitul mall. Tentu hal ini dapat dilakukan jika dapat dipisahkan harta mana yang diperoleh ketika masih Muslim dan mana yang diperolehnya setelah murtad. Apabila tidak bisa dipisahkan, maka sebaiknya semua kekayaannya dimasukkan ke baitul mall. ${ }^{9}$

Kewarisan beda agama dalam kompilasi hukum Islam tidak disebutkan secara jelas namun jika kita baca secara teliti maka dapat

${ }^{7}$ Fatchur Rahman, Ilmu Waris, (Bandung: Al-Ma'arif, 1994), Hlm. 98.

8 Muchit A. Karim, Problematika Hukum Kewarisan Islam Kontemporer Di Indonesia, (Jakarta:

Badan Litbang Dan Diklat Kementerian Agama RI, 2012), Hlm. 275.

9 Ilyas, Kedudukan Ahli Waris Non-Muslim Terhadap Harta Warisan Pewaris Islam Ditinjau Dari

Hukum Islam Dan Kompilasi Hukum Islam", Kanun Jurnal Ilmu Hukum, Vol. XVII, No. 65, (April, 2015), Hlm. 185. 
kita temukan bahwa dalam kompilasi hukum islam khususnya dalam pasal-pasal tertentu secara tersuarat tidak memperbolehkan adanya kewarisan beda agama

Dalam pasal 171 (b) menyatakan bahwa : "pewaris adalah orang yang pada saat meninggalnya atau yang dinyatakan meninggal berdasarkan putusan Pengadilan beragama Islam, meninggalkan ahli waris dan harta peninggalan." Serta dalam KHI dengan Pasal yang sama 171 (c) menyatakan bahwa: "ahli waris adalah orang yang pada saat meninggal dunia mempunyai hubungan darah atau hubungan perkawinan dengan pewaris, beragama Islam dan tidak terhalang karena hukum untuk menjadi ahli waris"10.

Pasal diatas menjelaskan tentang aturan kewarisan yang mengharuskan pewaris maupun ahli waris sama-sama beragama Islam, maka apabila salah satu diantara pewaris dan ahli waris beragama selain Islam maka diantara keduanya tidak boleh saling mewarisi, yang artinya hak saling mewarisi tersebut gugur.

Ketentuan agama seseorang dapat dilihat lewat identitasnya, hal ini tercantum dalam Kompilasi Hukum Islam pada Pasal 172 yang berbunyi: "ahli waris yang dipandang beragama Islam apabila diketahui dari kartu identitas atau pengakuan atau amalan atau kesaksian, sedangkan bayi yang baru lahir atau anak yang belum dewasa, beragama menurut ayahnya atau lingkungannya". ${ }^{11}$

Sedangkan dalam Kitab undang-undang hukum perdata (BW) tidak mengenal adanya perbedaan agam sehingga hal ini tidak menjadi halangan dalam hal waris-mewarisi, selama anak tersebut memiliki hubungan darah dengan pewaris maka hak anak tersebut tetap melekat. Sebagaiman yang telah disebutkan dalam Kitab UndangUndang Hukum Perdata dalam pasal 832 KUH Perdata yang menegaskan bahwa yang berhak menjadi ahli waris ialah keluarga sedarah, baik yang sah menurut undang-undang, maupun yang diluar perkawinan, dan suami atau istri yang hidup terlama. ${ }^{12}$

${ }^{10}$ Kompilasi Hukum Islam, Pasal 171 (B)(C)

${ }^{11}$ Ibid, Pasal 172

${ }^{12}$ Kitabundang-Undang Hukum Perdata, Pasal 832 
Waris Beda Agama (Analisis Putusan Perkara Kewarisan Beda Agama Dalam Putusan Ma 16/Kag/2018)

\section{Telaah yurisprudensi penyelesaian kasus waris beda agama (Putusan MA 16/Kag/20188)}

\section{a. Deskripsi Kasus Pada Putusan MA 16/Kag/2018}

Dalam kutipan akta nikah nomor 57/K/.PS/XI/1990 menyatakan bahwa telah terjadi pernikahan atas nama Ir. Muhammad Armaya bin rengreng beserta istrinya Evi Lany mosinta pada tanggal 1 november 1990 di bo'e, kabupaten poso . Pernikahan tersebut berlangsung selama 18 tahun daln selama itu keduanya tidak dikaruniai anak.

Pada tanggal 22 Mei 2008 Ir. Muhammad Armaya bin rengreng telah meninggal dunia dengan meninggalkan lima orang ahli waris yaitu : Halimah Daeng Baji (ibu); Dra. Hj. Murnihati binti Renreng, M.Kes. (saudara kandung); Dra. Hj. Muliyahati binti Renreng, M.Si. (Saudara kandung); Djelitahati bintirenreng, SST. (saudara kandung); dan Ir. Arsal bin Renreng (saudara kandung).

Almarhum Ir. Muhammad Armaya bin Renreng, M.Si disamping meninggalkan ahli waris juga meninggalkan harta bersama berupa:

1. Satu unit bangnan rumah permanen berserta tanahnya, seluas 216 m terletak di Jl. Hati Murah, Nomor 11, Kelurahan Mattoangin, Kecamatan Mariso, Makassar.

2. Satu unit bangunan rumah permanen berserta tanahnya, seluas $100 \mathrm{~m}$ terletak di Jalan Manuruki, Kompleks BTN Tabariah G 11/13.

3. Satu unit sepeda motor merk Honda Supra Fit Nopol DD 5190 KS warna hitam.

4. Uang Asuransi Jiwa dari PT Asuransi AIA Indonesia, sebesar Rp 50,000,000.00 (lima puluh juta rupiah).

Harta peninggalan yang telah disebutkan diatas diperoleh semasa hidup bersama penggugat menurut hukum harta ini menjadi harta bersama antara keduanya yang harta tersebut masih ada dalam penguasaan tergugat, penggugat sudah melakukan berbagai upaya agar harta tersebut dapat diberikan sesuai haknya secara kekeluargaan namun tergugsat tidak merespon hal tersebut sehingga penggugat mengajukan gugtan kepada pengadilan agama Makassar untuk mengadakan pembagian atas harta bersama tersebut menurut hukum islam. 
Yang menjadi pertimabangan mahkamah agung dalam memutus perkara iini diantaranya adalah: Bahwa perkawinan Tergugat/Pemohon Kasasi dengan Ir. Muhammad Armayabin Renreng, M.Si., alias Ir. Armaya Renreng sudah berlangsung cukup lama yaitu 18 tahun, berarti cukup lama pula Tergugat/ Pemohon Kasasi mengabdika diri pada Pewaris, karena itu walaupun Pemohon Kasasi non Muslim layak dan adil untuk memperoleh hak-haknya selaku istri untuk mendapat bagian dari harta peninggalan berupa wasiat wajibah serta bagian harta bersama sebagaimana yurisprudensi Mahkamah Agung RI. Persoalan kedudukan ahli waris non muslim juga sudah banyak dikaaji oleh kalangan Ulama diantaranya ulama Yusuf qardhawi, menafsirkan bahwa orang-orang muslim yang hidup berdampingan dengan damai tidak dapat dikategorikan kafir harbi, demikian demikian halnya pemohon kasasi bersam pewaris semasa hidup bergaul secara rukun damai meskipun berbsda keyakinan, karena itu patut dan layak pemohon kasasi memperoleh bagian dari harta peninggalan pewaris berupa wasiat wajibah.

Oleh karena itu berdasarkan pertimbangan diatas menurut pendapat mahkamah agung terdapat cukup alasan untuk mengabulkan permohonan kasasi: EVIE LANY MOSINTA dan membatalkan putusan pengadilan Agama Tinggi Makassar Nomor: 59/pdt.G/ 2009/PTA. Mks, tanggal 15 Juni 2009 M. bertepatan dengan tanggal 22 rajab $1430 \mathrm{H}$. yang menguatkan Putusan Pengadilan Agama Makassar Nomor 732/pdt.G/2008/PA. Mks, tanggal 2 Maret 2009M. bertepatan dengan tanggal 5 Robiul awal $1430 \mathrm{H}$.

Berdasarkan hal yang telah disebutkan diatas mahkamah Agung akan MENGADILI SENDIRI perkara tersebut yaitu:

Dalam Eksepsi:

- Menyatakan menolak eksepsi Tergugat;

Dalam Pokok Perkara:

1. Mengabulkan gugatan Penggugat untuk sebagian;

2. Menyatakan Ir. Muhammad Armaya bin Renreng, M.Si., alias Ir. Armaya Renreng telah meninggal dunia pada tanggal 22 Mei 2008; 
Waris Beda Agama (Analisis Putusan Perkara Kewarisan Beda Agama Dalam Putusan Ma 16/Kag/2018)

3. Menyatakan sebagai ahli waris almarhum Ir. Muhammad Armaya bin Renreng sebagai berikut:
a) Halimah Daeng Baji (ibu);
b) Dra. Hj. Murnihati binti Renreng, M.Kes. (saudara kandung);
c) Dra. Hj. Muliyahati binti Renreng, M.Si. (saudara kandung);
d) Djelitahati binti Renreng, SST. (saudara kandung); dan
e) Ir. Arsal bin Renreng (saudara kandung).

4. Menyatakan sebagai harta bersama almarhum Ir. Muhammad Armaya bin Renreng dengan tergugat adalah sebagai berikut:
a) Satu unit bangunan rumah permanen berserta tanahnya, seluas 216 m Terletak di Jl. Hati Murah, Nomor 11, Kelurahan Mattoangin, Kecamatan Mariso, Makassar.
b) Harga satu unit bangunan rumah permanen berserta tanahnya, seluas $100 \mathrm{~m} 2$ terletak di Jalan Manuruki, Kompleks BTN Tabariah G 11/13 Rp 70,000,000.00 (tujuh puluh juta rupiah).
c) Uang Asuransi Jiwa dari PT Asuransi AIA Indonesia, sebesar Rp 50,000,000.00 (lima puluh juta rupiah).

5. Menyatakan bahwa Tergugat berhak mendapat $1 / 2$ bagian dari harta bersama tersebut diatas dan setengah bagian lainnya merupakan harta warisan yang menjadi hak atau bagian ahli waris Ir. Muhammad Armaya bin Renreng, dengan rincian masing-masinsebagai berikut dengan pokok masalah 60 bagian:
a) Halimah Daeng Baji (ibu kandung) mendapat 10/60 bagian;
b) Evie Lany Mosinta (istri) mendapat wasiat wajibah 15/60 bagian.
c) Dra. Hj. Murnihati binti Renreng, M.Kes. (saudara perempuan) mendapat 7/60 bagian;
d) Dra. Hj. Muliyahati binti Renreng , M.Si. (saudara perempuan) mendapat $7 / 60$ bagian;
e) Djelitahati binti Renreng, SST. (saudara perempuan) mendapat 7/60 bagian; dan
f) Ir. Arsal bin Renreng (saudara laki-laki) mendapat 14/60 bagian.


6. Menghukum Tergugat untuk menyerahkan $1 / 2$ bagian dari harta bersama tersebut (harta warisan) kepada Penggugat;

7. Menyatakan jika bahagian dari harta bersama satu unit bangunan rumah permanen berserta tanahnya, seluas $216 \mathrm{~m} 2$ terletak di Jl. Hati Murah, Nomor 11 tidak dapat secara natura, maka dijual lelang kemudian diserahkan kepada para Penggugat;

8. Menyatakan Sita yang diletakkan oleh juru sita pada tanggal 16 Januari 2009 adalah sah dan berharga;

9. Menyatakan tidak menerima selain dan selebihnya;

10. Menghukum para Penggugat dan Tergugat untuk membayar biaya perkara secara tanggung renteng sebanyak $\mathrm{Rp}$ 3,436,000.00 (tiga juta empat ratus tiga puluh enamribu rupiah);

11. Menghukum Para Termohon Kasasi/para Penggugat untuk membayar biaya perkara dalam tingkat kasasi ini sebesar Rp 500,000.00 (lima ratus ribu rupiah);

\section{b. Analisis Putusan MA (16/Kag/2018)}

Pada Pasal 180 Kompilasi Hukum Islam, dikatakan bahwa Janda mendapat seperempat bagian bila pewaris tidak meninggalkan anak, dan bila pewaris meninggalkan anak maka janda mendapat seperdelapan bagian. Oleh karena Tergugat merupakan seorang non Muslim, maka ia tidak termasuk ke dalam ahli waris dan hanya berhak mendapat wasiat wajibah yang dalam Pasal 209 Kompilasi hukum Islam, dinyatakan bahwa wasiat wajibah sebanyak-banyaknya diberikan sebanyak $1 / 3$ (sepertiga).

Pemberian 1/4 harta warisan almarhum Muhammad Armaya bin Renreng, oleh Mahkamah Agung kepada tergugat memang tidak melebihi dari batas maksimal pemberian wasiat wajibah yang telah diatur dalam Kompilasi Hukum Islam. Namun Putusan ini di rasa belum memenuhi rasa keadilan karena hakim secara tidak langsung menyamakan kedudukannya sebagai isteri yang beragama muslim dalam hukum Islam. Dengan kata lain wasiat wajibah yang diberikan dalam putusan hakim tersebut seolah-olah membenarkan ahliwaris nonmuslim sama bagiannya dengan ahliwaris muslim terhadap harta warisan tersebut, hal ini sama dengan putusan hakim sebelumnya pada putusan nomor dan Putusan Mahkamah Agung RI Nomor : 368 
Waris Beda Agama (Analisis Putusan Perkara Kewarisan Beda Agama Dalam Putusan Ma 16/Kag/2018)

K/ AG/ 1995, tanggal 16 Juli 1998 dan Putusan Mahkamah Agunng RI Nomor : 51 K/ AG/ 1999, tanggal 29 September 1999

Dalam putusan tersebut, majelis hakim juga memberikan kewarisan kepada isteri non-Muslim berdasarkan jalan wasiat wajibah dengan argumen Yusuf Qardhawi yang menafsirkan bahwa orang-orang muslim yang hidup berdampingan dengan damai tidak dapat dikategorikan kafir harbi. Oleh Karena itu pemohon kasasi (isteri yang non-Muslim) bukan termasuk kafir harbi melainkan tergolong kepada seorang kafir yang hidup berdampingan dengan damai dengan orang Islam atau disebut dengan kafir dzimmi, maka dari itu pemohon kasasi berhak mendapat hak kewarisan dari pewaris (Islam) melalui wasiat wajibah. Di sini, secara tidak langsung majelis hakim membenarkan hak orang kafir dzimmi mewarisi harta orang Islam, karena mereka dapat hidup berdampingan dengan damai sesamanya.

Namun yang penulis temukan Yusuf al-Qaraḍawi menjelaskan dalam bukunya Hadyu al-Islam Fatawi Mu'a'sirah bahwa orang Islam dapat mewarisi dari orang non-Islam sedangkan orang non-Islam itu sendiri tidak boleh mewarisi dari orang Islam. Menurutnya Islam tidak menghalangi dan tidak menolak jalan kebaikan yang bermanfaat bagi kepentingan umatnya. Terlebih lagi dengan harta peninggalan atau warisan yang dapat membantu untuk mentauhidkan Allah, taat kepada-Nya dan menolong menegakkan agama-Nya. Bahkan sebenarnya harta ditujukan sebagai sarana untuk taat kepada-Nya, bukan untuk bermaksiat kepada-Nya. Maka darti itu Pertimbangan hukum yang dijadikan alternative dalam Putusan diatas, sudah sangat jelas berbeda dan terdapat ketidaksesuaian dengan pendapat yang dikemukakan oleh Ulama Yusuf AlQardhawi. ${ }^{13}$

Apabila pertimbangan yang digunakan oleh majelis hakim dilihat secara rinci, maka pertimbangan hukum tersebut terdapat kekeliruan. Mengenai Putusan tersebut, apabila dianalisis berdasarkan hukum Islam, bahwa putusan tersebut bertentangan dengan hukum Islam, karna antara dua orang yang berlainan agama tidak berhak saling mewarisi.

13 Al-Qaraḍawi, Fatwa-Fatwa Kontemporer, Terjemah Hadyu Al-Islam Fatawi Mu'asirah, Hlm. 850. 
Persoalan penetapan hak kewarisan terhadap ahli waris nonMuslim berdasarkan wasiat wajibah memang tidak diatur dalam aturan hukum manapun, baik dalam hukum perundang-undangan yang berlaku di Indonesia maupun dalam aturan hukum Islam (Al Quran dan hadis). Namun bukan berarti penerapan wasiat wajibah bagi ahli waris beda agama merupakan sesuatu yang salah melainkan hal ini merupakan Jalan keluar yang tempuh oleh hakim agar si ahli waris yang terhalang umtuk mendapatkan warisan oleh perbedaan agama dapat memperoleh haknya.

Wasiat wajibah merupakan wasiat yang pelaksanaannya tidak dipengaruhi atau tidak tergantung kepada kemauan atau kehendak si pewasiat, akan tetapi penguasa atau hakim sebagai aparat Negara mempunyai wewenang untuk memaksa atau memberikan putusan wasiat wajibah kepada kaum kerabat tertentu. wasiat wajibah itu mempunyai tujuan untuk mendistribusikan keadilan, yaitu memberikan bagian kepada ahli waris yang mempunyai pertalian darah namun nash tidak memberikan bagian yang semestinya, atau orang tua angkat dan anak angkat yang mungkin sudah banyak berjasa kepada si pewaris tetapi tidak diberi bagian dalam ketentuan hukum waris Islam, maka hal ini dapat dicapai jalan keluar dengan menerapkan wasiat wajibah sehingga mereka dapat menerima bagian dari harta pewaris. ${ }^{14}$

Muhammad Abduh dalam karyanya Tafsir Al-Manar dengan jelas menafsirkan boleh seorang pewaris Muslim mewariskan kepada orang tua dan kerabat yang belum masuk Islam Hal ini dilandaskan kepada ayat Dalam Al-Quran surah al-Baqarah ayat 180: "Diwajibkan atas kamu, apabila seorang di antara kamu kedatangan maut, jika ia meninggalkan harta yang banyak, berwasiat untuk ibu-bapak dan karib kerabatnya secara ma'ruf, kewajiban atas orang-orang yang bertakwa" Namun dalam sebuah hadis dijelaskan bahwa Nabi Muhammad saw berkata bahwa: "Tidak ada wasiat bagi ahli waris" (HR. Ahmad, Abu Dawud dan Tirmidzi). ${ }^{15}$

14 Abdul Manan, Aneka Masalah Hukum Perdata Islam Di Indonesia, (Jakarta: Kencana, 2006), Hal. 169.

15 Rahmat Yudistiawan, Putusan-Putusan Mahkamah Agung Yang "Bertentangan" Dengan Nash, Jurnal Aqlam, Journal Of Islam And Plurality, Volume 3, Nomor 2, Desember 2018, Hlm 256 
Waris Beda Agama (Analisis Putusan Perkara Kewarisan Beda Agama Dalam Putusan Ma 16/Kag/2018)

Dalam ayat diatas dijelaskan bahwa sesorang yang bertakwa berkewajiban meninggalkan wasiat kepada orang tua dan kerabatnya secara ma'ruf Namun dalam sebuah hadis dijelaskan Tidak ada wasiat bagi ahli waris, maka dalam menyelesaikan permasalahan ini perlu adanya hujjah karna disatu sisi mewajibkan adanya wasiat bagi orang tua dan karib kerabat yang merupakan ahli waris sedangkan di sisi lain tidak memperbolehkan adanya wasiat bagi ahli waris.

Bila dikaitkan dengan pendapat yang menegaskan bahwa salah satu penghalang ahli waris untuk mendapatkan haknya (salah satunya) adalah berbeda agama. Jika dikarenakan ahli waris berbeda agama dengan pewaris menjadkan dia tidak mendapatkan haknya, sedangkan ayat serta hadis di atas menyatakan bahwa tidak ada wasiat bagi ahli waris padahal wajib memberikan wasiat, maka metode wasiat wajibah merupakan penalaran yang pas untuk menyelesaikan konflik ahli waris non-Muslim. Sehingga tidak ada larangan bagi seorang pewaris Muslim untuk memberikan wasiatnya kepada ahli waris non-Muslim, bahkan hukumnya wajib bila pewaris meninggalkan harta yang banyak. Di sinilah nalar hukum Muhammad Abduh bermain ketika memosisikan ahli waris nonMuslim untuk mendapatkan haknya melalui wasiat wajibah. ${ }^{16}$

Namun alangkah lebih baiknya apabila perkara kewarisan beda agama terjadi, sebaiknya pewaris (Islam) harus berwasiat atau menghibahkan sebagian hartanya terhadap ahli waris yang nonMuslim (dari kerabat dekat), karena melalui jalan wasiat atau hibah ahli waris non-Muslim dapat menerima harta peninggalan dari pewaris Islam yang meninggal dunia, hal ini sesuai dengan Fatwa Majelis Ulama Indonesia (MUI) Nomor 5/MUNAS VII/MUI/9/2005 tentang Kewarisan Beda Agama, yaitu:

1. Hukum waris tidak memberikan hak saling mewarisi antar orang-orang yang berbeda agama (antara Muslim dengan non- Muslim).

2. Pemberian harta (warisan) antar orang yang berbeda agama hanya dapat dilakukan dalam bentuk hibah, wasiat, dan hadiah.

Wasiat yang dimaksud dalam Fatwa MUI di atas adalah wasiat pada umumnya, dalam artian seseorang yang telah meninggal

${ }^{16}$ Ibid, 257 
dunia yang berwasiat langsung kepada orang (kerabat) non-Muslim yang dikehendakinya ketika masih hidup, bukan dengan jalan wasiat wajibah. Karena pada dasarnya orang non- Muslim tidak berhak mendapat hak kewarisan dalam bentuk apapun dari pewaris yang beragama Islam, namun melalui Fatwa MUI tersebut, Islam telah memberikan satu alternatif yang dirasa sangat baik dalam menyelesaikan permasalahan kewarisan beda agama bahwa kerabat non-Muslim dapat menerima hak kewarisan berdasarkan jalan wasiat, hibah, dan hadiah saja tidak melalui jalan wasiat wajibah. Dikarenakan wasiat yang dimaksud dalam Fatwa MUI tersebut tidak dapat dikategorikan sebagai wasiat wajibah, karena pemberian wasiat wajibah tidak dapat diberikan kepada orang non-Muslim. Wasiat wajibah merupakan pembagian hak kewarisan tertinggi dalam Islam, dan mengenai pemberian hak kewarisan berdasarkan jalan wasiat wajibah juga telah ditentukan siapa yang berhak mendapatkannya, sebagaimana telah disebutkan dalam KHI.

Fatwa MUI mengenai kewarisan beda agama sebagaimana disebutkan di atas tidak diberlakukan oleh majelis hakim yang telah memeriksa serta memutuskan perkara kewarisan beda agama antara suami (pewaris) yang beragama Islam dengan isteri yang beragama non-Muslim. Dalam perkara ini majelis hakim memutuskan bahwa ahli waris yang non-Muslim berhak mendapatkan hak kewarisan berdasarkan wasiat wajibah dengan pertimbangan hukum yang disebutkan dalam Putusan Nomor 16 K/ AG/2010, sebagaimana yang telah disebutkan diatas pada halaman sebelumnya. Dikarenakan Indonesia bukan Negara Islam, maka hukum yang berlakupun bukan hukum Islam. Namun dilihat dari aspek sosialgeografisnya, Indonesia merupakan negara dengan berbagai suku, budaya dan agama. faktor tersebut yang menyebabkan Indonesia bukan merupakan Negara Islam dan tidak sepenuhnya tunduk pada hukum Islam. Meskipun tidak dapat dipungkiri bahwa sebagian besar aturan yang berlaku di Indonesia dipengaruhi oleh Hukum Islam. Selain dipengaruhi oleh Hukum Islam, aturan-aturan yang berlaku di Indonesia pula dipengaruhi oleh hukum adat dan hukum barat. Dalam hukum adat, yang menjadi dasar utamanya adalah keseimbangan dan kemaslahatan umat, sehingga dalam perkara waris beda agama sejumlah hakim mengeluarkan putusan hukum dengan 
Waris Beda Agama (Analisis Putusan Perkara Kewarisan Beda Agama Dalam Putusan Ma 16/Kag/2018)

pertimbangan wasiat wajibah dengan alasan keadilan dan kemanusiaan,

\section{Penutup}

Dalam hal waris beda agama, ulama berbeda pendapat. Ada yang mengatakan bahwa orang non-Muslim tidak bisa mewarisi harta orang Muslim sesuai hadist Nabi Muhammad SAW. dan Nabi pernah mempraktekkan pada saat paman beliau meninggal, yaitu Abu Thalib, semua harta paman diberikan kepada anaknya yang masih Kafir, yaitu 'Uqail dan Thalib. Sementara anak-anaknya yang telah masuk Islam, yaitu 'Ali dan Ja'far tidak diberikan. Jumhur ulama selain Malikiyah sepakat bahwa yang dimaksud dengan berbeda agama adalah antara Islam dengan non-Islam, baik kristen, budha, hindu dan lain-lain. Sedangkan non-Islam tersebut bisa saling mewarisi diantara mereka. Sedangkan Yusuf al-Qardhawi berpendapat bahwa orang Muslim bisa mewarisi harta orang nonMuslim, dan tidak sebaliknya.

Sedangkan mengenai harta orang murtad, menurut ulama mereka mempunyai kedudukan hukum tersendiri karena mereka telah memutuskan tali syari'ah dan melakukan kejahatan agama. Harta peninggalannya dimasukkan ke baitul mall sebagai harta fai' atau rampasan, dan digunakan untuk kepentingan umum.

Berdasarkan pertimbangan hakim dalam putusan nomor 16/k/ag/2010 dapat dilihat adanya kekeliruan terutama penerapan wasiat wajibah untuk isteri non muslim terhadap harta peninggalan suami, karena jika dilihat dalam beberapa Yurisprudensi penerapkan wasiat wajibah terhadap non muslim tidak ada kesamaan porsinya dan seolah-olah menyamakan kedudukannya dengan ahli waris muslim hal ini sangat tidak memenuhi rasa keadilan dan bertentangan dengan Fatwa Majelis Ulama Nomor 5/MUNAS VII/MUI/9/2005 tentang Kewarisan Beda Agama

\section{Daftar Rujukan}

Al-Bukhari, Al-Imam Abu Abdillah Muhammad ibn Ismail ibn alMugirah ibn Bardizbah, Sahih al-Bukhari, Juz 4, Beirut Libanon: Dar al-Fikr, 1410 H/1990 M, hlm. 194, 
Al-Qaraḍawi, Yusuf, Fatwa-Fatwa Kontemporer, terjemah Hadyu al-Islam Fatawi Mu'asirah, Jilid ke-3 (Jakarta: Gema Insani Press, 2002), hlm. 850.

Ilyas, Kedudukan Ahli Waris non-Muslim Terhadap Harta Warisan Pewaris Islam Ditinjau Dari Hukum Islam dan Kompilasi Hukum Islam", Kanun Jurnal Ilmu Hukum, Vol. XVII, No. 65, (April, 2015)

Karim, Muchit A., Problematika Hukum Kewarisan Islam Kontemporer di Indonesia, (Jakarta: Badan Litbang dan Diklat Kementerian Agama RI, 2012)

Kitab undang-undang Hukum Perdata

Kompilasi Hukum islam

Maimun, Pembagian Hak Waris Terhadap Ahli Waris Beda Agama Melalui Wasiat Wajibah dalam Perspektif Hukum Kewarisan Islam, Jurnal Asas, Vol. IX, No. 1, (Januari 2017)

Manan, Abdul, Aneka Masalah Hukum Perdata Islam di Indonesia, (Jakarta: Kencana, 2006)

Rafiq, Ahmad, Fiqih Mawaris, (Jakarta: PT Raja Grafindo Persada, 1993)

Rahman, Fatchur, Ilmu Waris, (Bandung: Al-Ma'arif, 1994)

Tohari, Chamim, Rekonstruksi Hukum Kewarisan Beda Agama, Mazahib jurnal Pemikiran Hukum Islam, Vol. XVI, No. 1 (Juni 2017)

Yudistiawan Rahmat, Putusan-Putusan Mahkamah Agung Yang "Bertentangan" Dengan Nash, Jurnal Aqlam, Journal Of Islam And Plurality, Volume 3, Nomor 2, Desember 2018, hlm 256 